\title{
Tropical Volcanic Soils From Flores Island, Indonesia
}

\author{
Hikmatullah and Kesumo Nugroho ${ }^{1}$ \\ Received 30 November 2009 / accepted 8 January 2010
}

\begin{abstract}
Tropical Volcanic Soils from Flores Island, Indonesia (Hikmatullah and K Nugroho): Soils that are developed in tropical region with volcanic parent materials have many unique properties, and high potential for agricultural use. The purpose of this study is to characterize the soils developed on volcanic materials from Flores Island, Indonesia, and to examine if the soils meet the requirements for andic soil properties. Selected five soils profiles developed from andesitic volcanic materials from Flores Island were studied to determine their properties. They were compared in their physical, chemical and mineralogical characteristics according to their parent material, and climatic characteristic different. The soils were developed under humid tropical climate with ustic to udic soil moisture regimes with different annual rainfall. The soils developed from volcanic ash parent materials in Flores Island showed different properties compared to the soils derived from volcanic tuff, even though they were developed from the same intermediary volcanic materials. The silica contents, clay mineralogy and sand fractions, were shown as the differences. The different in climatic conditions developed similar properties such as deep solum, dark color, medium texture, and very friable soil consistency. The soils have high organic materials, slightly acid to acid, low to medium cation exchange capacity (CEC). The soils in western region have higher clay content and showing more developed than of the eastern region. All the profiles meet the requirements for andic soil properties, and classified as Andisols order. The composition of sand mineral was dominated by hornblende, augite, and hypersthenes with high weatherable mineral reserves, while the clay fraction was dominated by disordered kaolinite, and hydrated halloysite. The soils were classified into subgroup as Thaptic Hapludands, Typic Hapludands, and Dystric Haplustands.
\end{abstract}

Keywords: Andisols, andic soil properties, Flores Island, volcanic materials

\section{INTRODUCTION}

In Indonesia, the volcanic soils have a total area of 5.4 millions ha or $2.9 \%$ of the total Indonesia archipelago (Subagjo et al. 2004), whereas in the world the soils occupy about $0.84 \%$ of the earth's surface (Leamy, 1984; Takahashi and Shoji 2002). The volcanic soils have widely distributed along a belt in islands of Sumatra, Java, Bali, Nusa Tenggara, Celebes, and Halmahera. The investigation of the volcanic soils in Indonesia was initiated by some researchers, such as Van Schuylenborgh (1957), Dudal and Soepraptohardjo (1960), and Tan (1965). Some studies of the volcanic soils in last decade have been reported, especially from Sumatra (Fiantis and Van Ranst 1997; Alkasuma and Badayos 2003), Java (Arifin and Hardjowigeno 1997; Van Ranst et al.
2002; Fauzi and Stoops 2004; Yatno and Zauyah 2008), North Sulawesi (Hikmatullah 2008), and Dompu Sumbawa (Sukarman et al. 1993).

Soils that are developed on volcanic parent materials of Quarternary age have important role, due to unique morphological, physical, chemical and mineralogical properties and high potential for agricultural development to produce many kinds of agricultural commodities. The volcanic soils, in most cases are classified into Andisols order but not all volcanic soils are Andisols, depend on the weathering stage and soil forming processes (Shoji et al. 1993). Many studies of the volcanic soils have been reported from certain countries, such as from Japan (Shoji and Ono 1978), United States (Wada et al. 1986; Shoji et al. 1988), Mexico (Prado et al. 2007), Ecuador (Zehetner et al. 2003; Buytaert et al. 2007), Costa

\footnotetext{
${ }^{1}$ Indonesian Center for Agricultural Land Resource Research and Development Agency for Agricultural Research and Development. Present address: J1. Ir. H. Juanda No. 98, Bogor 16123, Indonesia

Corresponding authors e-mail: hkmt_2006@yahoo.co.id

J Trop Soils, Vol. 15, No. 1, 2010: 83-93

ISSN 0852-257X
} 
Rica (Nieuwenhuyse et al. 1993), New Zealands (Parfitt et al. 1983), Portugal (Madeira et al. 1994), Greece (Moustakas and Georgoulias 2005) and Rwanda Africa (Nizeyimana 1997).

Soil resources of the Flores Island with a total area of $1.4 \mathrm{M}$ ha had been documented in reconnaissance level. About $0.45 \mathrm{Mha}$ of the soil resources was developed from volcanic parent materials, and dominantly grouped into Andisols, Mollisols and Inceptisols orders (CSAR 1997). The composition of sand mineral fraction of the volcanic materials consists of plagioclase, andesine, pyroxene, hypersthene, augite and olivine (Suwarna et al. 1990; Kusumadinata et al. 1981).

The main characteristics of the soils developed from volcanic materials, such as Andisols, have unique characteristics, such as dark color in the topsoils, high content of organic materials, low bulk density, high porosity, high $\mathrm{P}$ retention, high content of acid ammonium oxalate extractable $\mathrm{Al}, \mathrm{Fe}$ and $\mathrm{Si}$ $\left(\mathrm{Al}_{\mathrm{o}}, \mathrm{Fe}_{\mathrm{o}}, \mathrm{Si}_{\mathrm{o}}\right)$, and high weatherable minerals reserve (Shoji et al. 1993; Nanzyo 2002). In general, the Andisols order are found in high plain (>700 $\mathrm{m}$ asl.), but it also found in low plain, such as in North and West Sumatra, as reported by Tan (1998). Andisols should meet the requirements for andic soil properties.
The andic soil properties are based on soil physical, chemical, and mineralogical properties, consisting of sand content, bulk density, $\mathrm{P}$ retention, content of $\left(\mathrm{Al}_{\mathrm{o}}+0,5 \mathrm{Fe}_{\mathrm{o}}\right)$ extractable ammonium oxalate, and volcanic glasses (Soil Survey Staff 2006).

The objective of the study was to characterize the andic properties of the soils which were originated from the parent materials of five volcanoes with different climatic conditions in Flores Island, Indonesia. The characterization were executed according to the methods and criteria of the Soil Taxonomy (Soil Survey Staff 2006).

\section{MATERIALS AND METHODS}

\section{Study Area}

There are five soils profile from five different locations that had been observed their characteristics (Table 1). The soils were taken from Flores Islands, eastern part of Java and Bali islands. Flores island, Indonesia, with a total area of 1.4 millions ha, is located at coordinate of $08^{\circ} 10^{\prime}-09^{\circ} 05^{\prime}$ 'South Latitude, and $119^{\circ} 45^{\prime}-123^{\circ} 10^{\prime}$ East Longitude, with elevation of $0-2,350 \mathrm{~m}$ above sea level. The location of soil profiles is presented in Figure 1.
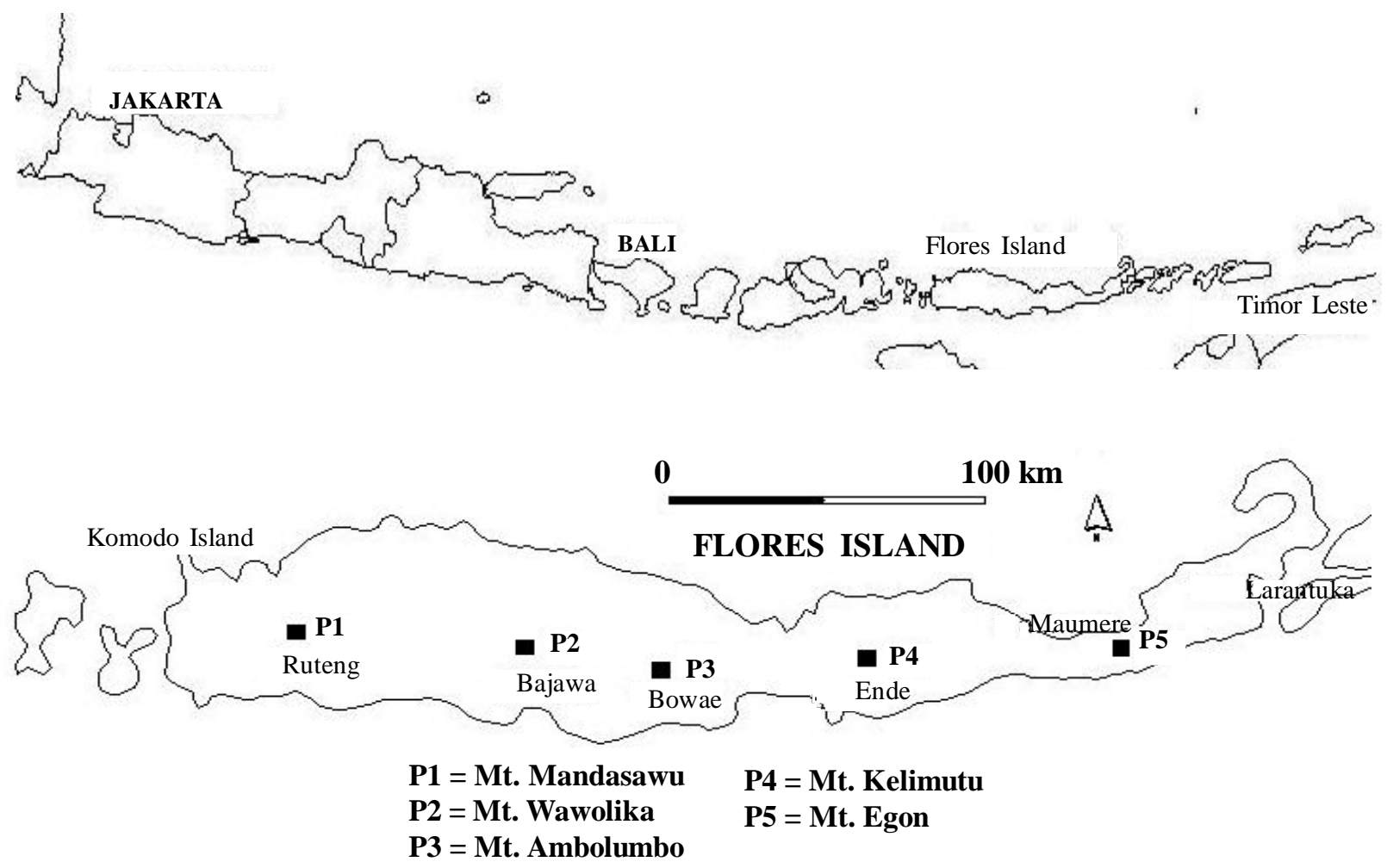

Figure 1. Location of soil profiles in Flores Island. 
Table 1. Location, slope, parent material, land use and elevation of the profiles studied.

\begin{tabular}{cllcllc}
\hline Profile & Location & Volcano & \% Slope & Parent material & Landuse & Elevation (m, asl.) \\
\hline P1 & Ruteng & Mt. Mandasawu & 45 & Andesitic ash & Forest & 1,500 \\
P2 & Bajawa & Mt. Wawolika & 32 & Andesitic ash & Pine forest & 1,300 \\
P3 & Boawae & Mt. Ambolumbo & 30 & Andesitic tuffs & Shrub, bush & 1,100 \\
P4 & Ende & Mt. Kelimutu & 40 & Andesitic tuffs & Vegetables, shrub & 1,400 \\
P5 & Maumere & Mt. Egon & 32 & Andesitic tuffs & Shrub & 750 \\
\hline
\end{tabular}

The climate of the island is generally humid tropical region. Rainfall data from five stations (Table 2) showed an increasing amount of rainfall from east to west area of the island; with average annual rainfall vary from 1,206 $\mathrm{mm}$ in Maumere, to 3,070 $\mathrm{mm}$ in Ruteng. Rain season is occurring in November to March. The average temperature varies between 26.6-29.3 $3^{\circ} \mathrm{C}$ in Maumere, and $18.5-20.8^{\circ} \mathrm{C}$ in Ruteng. Flores Island belongs to Afa climate type in western part with B rainfall type, and Awa type in eastern part with D rainfall type (Schmidt and Ferguson 1951). Calculated water balance using Newhall Simulation Model (Wambeke et al. 1986) showed udic soil moisture regime in the western part and ustic soil moisture regime in the eastern part. The soil temperature regime belongs to isohyphertermic for the area less than $1,000 \mathrm{~m}$ and isothermic for area more than $1,000 \mathrm{~m}$ above sea level.

\section{Methodology}

In generally, the soil profiles were compared, following the differences in their lithological characteristics (parent material) including their occurrences. The studied profiles were examined according to their climatic condition (annual rainfall).

Samples were air-dried, crushed and sieved to pass a $2 \mathrm{~mm}$ sieve. In the fine earth fraction, the sand fraction was determined by wet sieving, and the silt and clay fraction using the pipette method. Bulk density (BD) was determined in $33 \mathrm{kPa}$ and 1,500
$\mathrm{kPa}$ water retention. Organic matter was determined by dry combustion using the method of Walkley and Black. Soil $\mathrm{pH}$ was measured in a suspension of soil in water (1:1) and in $0.01 \mathrm{M} \mathrm{KCl}(1: 10)$. Exchangeable cations $(\mathrm{Ca}, \mathrm{Mg}, \mathrm{K}$ dan $\mathrm{Na})$ and cation exchange capacity (CEC) of soils were determined in ammonium acetate extraction $\mathrm{pH}$ 7.0. All the above procedures of soil sample analyses were outlined in Soil Survey Laboratory Method Manual (Burt 2004).

To test amorphous materials and andic soil properties, soil $\mathrm{pH}$ in $1 M \mathrm{NaF}$ was measured at 1:50 after exactly 60 minutes. Phosphate retention was determined using the method of Blakemore et al. (1987). Dissolution analyses were conducted for acid ammonium oxalate extractable $\mathrm{Al}, \mathrm{Fe}$ and $\mathrm{Si}\left(\mathrm{Al}_{\mathrm{o}}, \mathrm{Fe}_{\mathrm{o}}\right.$, $\mathrm{Si}_{\mathrm{o}}$ ), and ammonium pyrophosphate extractable $\mathrm{Al}$ and $\mathrm{Fe}\left(\mathrm{Al}_{\mathrm{p}}, \mathrm{Fe}_{\mathrm{p}}\right)$ using the method of Blakemore et al. (1987).

Mineral composition of sand fraction was determined by line counting method, using polarization microscope (Buurman 1990). The clay fraction analyses used X-Ray Diffraction (XRD) with standard treatment of $\mathrm{Mg}^{2+}$ saturation. Soil classification was determined using the Keys to Soil Taxonomy (Soil Survey Staff 2006) at subgroup level.

For the purposes of the study, five selected profiles from the above volcanoes were described in the field, and soil samples were taken by horizons for physical, chemical and mineralogical analyses in the laboratory. The distribution of the profiles and

Table 2. Average monthly rainfall in the Flores Island.

\begin{tabular}{|c|c|c|c|c|c|c|c|c|c|c|c|c|c|c|}
\hline Station & Elev. & Jan & Feb & Mar & Apr & May & Jun & Jul & Aug & Sep & Oct & Nov & Dec & Total \\
\hline & & & & & & & & $\begin{array}{c}\mathrm{mm} \\
86\end{array}$ & & & & & & 70 \\
\hline & & & & & & & & & 36 & & & & & 72 \\
\hline & 800 & & & 25 & 10 & & & & 5 & & 73 & & 5 & 1,493 \\
\hline & 10 & & & 17 & 58 & 125 & 3 & $61+2$ & 46 & 60 & 142 & & 15 & 1,509 \\
\hline laumere & 25 & 210 & $2 \angle \mathrm{V}$ & 162 & 77 & 70 & 46 & 46 & 4 & 25 & 21 & 131 & 190 & 1,206 \\
\hline
\end{tabular}


Table 3. Morphological and physical properties of the profile studied.

\begin{tabular}{|c|c|c|c|c|c|c|c|c|c|c|c|c|}
\hline Horizon & Depth & $\begin{array}{l}\text { Matrix } \\
\text { color }\end{array}$ & class & $\begin{array}{r}\text { Texture } \\
\text { sand }\end{array}$ & $\begin{array}{l}\text { (1) } \\
\text { silt }\end{array}$ & clay & Structure $^{2)}$ & $\begin{array}{c}\text { Bulk } \\
\text { density } \\
\text { (BD) }\end{array}$ & $\begin{array}{l}\text { Total } \\
\text { pore } \\
\text { space }\end{array}$ & $\begin{array}{c}\mathrm{pF} \\
2.54\end{array}$ & $\begin{array}{l}\mathrm{pF} \\
4.2\end{array}$ & $\begin{array}{c}\text { A vailable } \\
\text { water }\end{array}$ \\
\hline & $\mathrm{cm}$ & moist & & $-\overline{----}$ & $-\%$ & 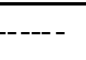 & & $\mathrm{g} \mathrm{cm}^{-3}$ & $-\cdots$ & -19 & $\%$ vol. & -1 \\
\hline \multicolumn{13}{|c|}{ P1: Mt. Mandasawu, Ruteng (1,500 m asl.). } \\
\hline A & $0-25$ & $10 \mathrm{YR} 3 / 2$ & $\mathrm{SiL}$ & 23 & 50 & 27 & 2.f.g & 0.43 & 83.9 & 37.2 & 18.6 & 18.6 \\
\hline Bw1 & $25-44$ & 10 YR $3 / 3$ & SiL & 14 & 74 & 12 & 1.m.g & 0.37 & 86.1 & 53.7 & 15.0 & 38.7 \\
\hline 2Bw1 & $44-69$ & 10 YR $3 / 3$ & SiL & 12 & 75 & 13 & 1.m.sb & 0.37 & 86.2 & 58.1 & 11.6 & 46.5 \\
\hline $2 \mathrm{Bw} 2$ & $69-108$ & 10 YR $3 / 6$ & SiL & 14 & 73 & 13 & 1.m.sb & & & & & \\
\hline $2 \mathrm{Bw} 3$ & $108-143$ & 10 YR $3 / 4$ & $\mathrm{SiCL}$ & 19 & 51 & 30 & 2.c.sb & & & & & \\
\hline $2 \mathrm{Bw} 4$ & $143-173$ & $10 \mathrm{YR} 3 / 6$ & $\mathrm{SiL}$ & 18 & 64 & 18 & 1.c.sb & & & & & \\
\hline \multicolumn{13}{|c|}{ P2: Mt. Wawolika, Bajawa (1,300 m asl.). } \\
\hline A1 & $0-15$ & 10 YR 3/1 & SiL & 28 & 61 & 11 & 2.m.g & 0.75 & 71.8 & 36.5 & 21.8 & 14.7 \\
\hline A2 & $15-29$ & 10 YR $2 / 1$ & SiL & 38 & 53 & 9 & 2.f.g & & & & & \\
\hline Bw1 & $29-53$ & 10 YR $2 / 1$ & $\mathrm{SiL}$ & 32 & 55 & 13 & 1.f.sb & 0.63 & 76.2 & 42.0 & 19.9 & 22.1 \\
\hline Bw2 & $53-75$ & 10 YR $2 / 1$ & SiL & 37 & 52 & 11 & 1.f.sb & & & & & \\
\hline Bw3 & 75-94 & 10 YR $2 / 1$ & SiL & 29 & 52 & 19 & 1.f.sb & & & & & \\
\hline $\mathrm{BC}$ & $94-110$ & 10 YR $2 / 1$ & $\mathrm{~L}$ & 39 & 47 & 14 & 1.f.sb & & & & & \\
\hline $\mathrm{C}$ & $110-135$ & $10 \mathrm{YR} 4 / 3$ & SL & 59 & 31 & 10 & 1.f.sb & & & & & \\
\hline \multicolumn{13}{|c|}{ P3: Mt. Ambolumbo, Boawae (1,100 m asl.). } \\
\hline A1 & $0-14$ & 10 YR $3 / 2$ & $\mathrm{SL}$ & 72 & 24 & 4 & 2.f.g & 0.74 & 57.1 & 24.7 & 14.3 & 10.4 \\
\hline A2 & $14-32$ & 10 YR $3 / 4$ & SL & 68 & 29 & 3 & 2.f.g & & & & & \\
\hline Bw1 & $32-62$ & $10 \mathrm{YR} 4 / 4$ & SL & 63 & 28 & 9 & 1.f.g & 0.85 & 55.3 & 27.1 & 20.3 & 6.8 \\
\hline Bw3 & $62-100$ & 10 YR 4/6 & $\mathrm{SL}$ & 66 & 26 & 8 & 1.vf.sb & & & & & \\
\hline $\mathrm{BC}$ & $100-130$ & 10 YR 5/4 & $\mathrm{SCL}$ & 62 & 10 & 28 & 1.vf.sb & & & & & \\
\hline \multicolumn{13}{|c|}{ P4: Mt. Kelimutu, Ende (1.400 m asl.). } \\
\hline $\mathrm{Ah}$ & $0-16$ & $10 \mathrm{YR} 4 / 2$ & SL & 64 & 25 & 11 & 2.f.g & 0.68 & 74.4 & 27.8 & 17.8 & 10.0 \\
\hline Bw1 & $16-57$ & 10 YR 5/4 & SL & 64 & 27 & 9 & 1.f.sb & 0.91 & 62.1 & 33.0 & 13.9 & 19.1 \\
\hline Bw2 & $57-90$ & $10 \mathrm{YR} 3 / 2$ & SL & 63 & 30 & 7 & 1.f.sb & & & & & \\
\hline $2 \mathrm{Ah}$ & $90-126$ & 10 YR $4 / 3$ & $\mathrm{SL}$ & 73 & 24 & 3 & 1.f.sb & & & & & \\
\hline $2 \mathrm{Bw}$ & $126-190$ & 10 YR $5 / 3$ & $\mathrm{~L}$ & 72 & 26 & 2 & 1.f.sb & & & & & \\
\hline \multicolumn{13}{|c|}{ P5: Mt. Egon, Maumere (750 m asl.). } \\
\hline A & $0-15$ & 10 YR $3 / 3$ & $\mathrm{~L}$ & 34 & 47 & 19 & 1.f.g & 0.80 & 68.8 & 28.6 & 16.6 & 12.0 \\
\hline Bw1 & $15-43$ & $10 \mathrm{YR} 4 / 3$ & LS & 79 & 17 & 4 & 1.m.g & 0.73 & 72.4 & 26.6 & 18.7 & 7.9 \\
\hline Bw2 & $43-70$ & 10 YR 4/4 & LS & 80 & 16 & 4 & 1.m.sb & & & & & \\
\hline 2Bw1 & 70-96 & 10 YR 4/6 & SL & 62 & 30 & 8 & 1.m.sb & & & & & \\
\hline $2 \mathrm{Bw} 2$ & $96-150$ & 10 YR 4/6 & $\mathrm{SL}$ & 75 & 17 & 8 & 1.c.sb & & & & & \\
\hline
\end{tabular}

${ }^{1)}$ Texture class: $\mathrm{L}=$ loam; $\mathrm{SL}=$ sandy loam; $\mathrm{SCL}=$ sandy clay loam: $\mathrm{SiL}=$ silt loam; $\mathrm{SiCl}=$ silty clay loam; $\mathrm{LS}=$ loamy sand, 2) Structure development grade: 1 = weak; 2 = moderate; size vf = very fine; $\mathrm{f}=$ fine; $\mathrm{m}=$ medium; $\mathrm{c}=$ coarse; shape: $\mathrm{g}=$ granular; sb = subangular blocky.

their environments are presented in Table 1 and Figure 1.

\section{RESULTS AND DISCUSSION}

\section{Morphological Properties}

All the soil profiles had deep solum $(>100 \mathrm{~cm})$ with variation of A horizon from 15 to $32 \mathrm{~cm}$, and $\mathrm{B}$ horizon more than $75 \mathrm{~cm}$ (Table 3). The A horizon of profile $\mathrm{P} 4$ and $\mathrm{P} 5$ is thinner than the others which is 86 probably affected by agriculture use. The color of A horizon is very dark brown (10YR2/1-3/3) to dark grayish brown (10YR4/2). While the B horizon have lighter color to dark brown (10YR3/4) to brown (10YR4/6), except for profile $\mathrm{P} 2$ has very dark brown (10YR2/1).

The darker color in A horizon than in B horizon is related to higher content of organic materials in A horizon. The horizon sequences of all the profiles were characterized by A umbric epipedon, Bw cambic diagnostic horizons, and $\mathrm{C}$ horizons, as $\mathrm{A}-\mathrm{Bw}-\mathrm{C}$. The 
horizon sequence indicated that the soils have moderate profile development (Van Ranst et al. 2002).

The A and B horizons of the profiles show weak structural development, indicated by subangular blocky breaking to fine if pressed by hand, and have very friable to friable consistency in moist condition. The friable properties have benefits in agricultural use, because of it easy to tillage and better roots development. The smeary or thixotropic properties, as an indication of high content of amorphous materials are significant in profile $\mathrm{P} 1$ and $\mathrm{P} 2$, but not clear in other profiles. This may be affected by high sand content indicating the parent materials have not yet much weathered. The profiles showed little different morphological properties, where the soil profiles from the western region (profile P1 and P2) are more developed than the eastern region.

\section{Physical Properties}

The soil profiles showed variation in silt and sand content. The soil texture varies from silt loam, loam, sandy loam and loamy sand that classified as medium to slightly coarse classes (Soil Survey Division Staff 1993). The sand distribution varies from 23 to $72 \%$ in A horizon, and from 12 to $80 \%$ in B horizon. On the contrary, the clay content is low, varies from 4 to $27 \%$ in A horizon, and from 9 to $30 \%$ in B horizon. It is clear that the soil texture of the soil profiles from eastern Flores Island has high sand content (sandy loam to loamy sand), while in the western it is high silt content (silt loam). The high sand content indicated that the soil has lower weathering stage as showed in structural development features. Niuwenhuys et al. (1993) reported that in wet tropical climate in Costa Rica, the formation of Andisols from sandy volcanic materials need of time as long as 2000 years. But Wada (1985) mentioned that the formation of Andisols with full horizons of A-Bw-C in wet climate in Japan need a time at least 1000 years. The soils from volcanic materials with high sand content were similar to the volcanic materials found in Mt. Soputan, North Sulawesi (Hikmatullah 2008) and Mt. Kimangbuleng in Flores Island (Sukarman et al. 1999).

The bulk density (BD) has variation from 0.37 to $0.91 \mathrm{~g} \mathrm{~cm}^{-3}$, both in A and B horizons. The low BD values meet one of the requirements of andic soil materials for the first group in Soil Taxonomy (Soil Survey Staff 2006). The amorphous material, i.e. allophone is one of the most important non-crystalline materials contributing to the low bulk density of the soils through the development of porous soil structure (Nanzyo et al. 1993). The high total pore spaces for all the soils profiles were also contribute to low bulk density. The content of available water percentages was higher in the subsoils than topsoils, that it may be related to large amount of organic matter and allophone content.

\section{Chemical Properties}

The organic carbon content of the soil profiles is generally high in A horizons and decrease to B horizons (Table 4). In A horizon the organic carbon content varied from 2.67 to $9.24 \%$ as classified as high. But in B horizons the organic carbon content varied from 0.31 to $7.37 \%$ as classified as low to high.

In general, the value of soil- $\mathrm{pH}_{\mathrm{H} 2 \mathrm{O}}$ varied from 5.1 to 6.6 in A horizons, and from 5.3 to 6.6 in $\mathrm{B}$ horizons, as classified as relatively high, except for soil profiles $\mathrm{P} 1$ and $\mathrm{P} 4$ is more acid. The relatively high soil $\mathrm{pH}$ is benefit for crop growth, because of available soil nutrient and favorable for the growth. The relatively high $\mathrm{pH}$ in profiles $\mathrm{P} 2, \mathrm{P} 3$, and $\mathrm{P} 5$ may be caused by the nature of parent materials that not much yet weathered, and lower amount of rainfall that leaching bases are not intensively occurred.

The exchangeable bases $(\mathrm{Ca}, \mathrm{Mg}, \mathrm{K}$, and $\mathrm{Na}$ ) were generally dominated by high content of $\mathrm{Ca}$ and $\mathrm{Mg}$ that classified as low to medium. The content of bases reflected that the soils contain of nutrient bases that caused of higher $\mathrm{pH}(>6.0)$. The base saturation varied from low to high (28-78\%), except for profile $\mathrm{P} 1$ is very low (4-10\%) indicating intensive leaching due to highest rainfall in western Flores Island.

The soil cation exchange capacity (CEC) is vary from low $\left(<16 \mathrm{cmol}_{\mathrm{c}} \mathrm{kg}^{-1}\right)$ to high $\left(>24 \mathrm{cmol}_{\mathrm{c}} \mathrm{kg}^{-1}\right)$ both in A and B horizons. The low soil CEC is probably caused by low content of clay and high of sand, especially in profile P3, P4 and P5.

\section{Andic Properties and Soil Classification}

The requirements for andic soil properties according to Soil Taxonomy (Soil Survey Staff 2006) can be grouped into 2 groups. The soils have to be classified as andic soils if meet one of the following groups. The first group is having: (a) Organic C content $<25 \%$, (b) BD $\leq 0.90 \mathrm{~g} \mathrm{~cm}^{-3}$ at retention 33 $\mathrm{kPa}$, (c) $\mathrm{P}$ retention $\geq 85 \%$, and (d) $\left(\mathrm{Al}_{\mathrm{o}}+0.5 \mathrm{Fe}_{\mathrm{o}}\right)$ content $\geq 2,0 \%$. The second group is having: (a) Organic C content $<25 \%$, (b) sand fraction content $\geq$ $30 \%$, (c) P retention $\geq 25 \%$, (d) $\left(\mathrm{Al}_{\mathrm{o}}+0.5 \mathrm{Fe}_{\mathrm{o}}\right)$ content $\geq 0,4 \%$; (e) volcanic glass content $\geq 5 \%$, and (f) index 
Hikmatullah and K Nugroho: Volcanic Soils from Flores

Table 4. Chemical properties of the profile studied.

\begin{tabular}{|c|c|c|c|c|c|c|c|c|c|c|c|}
\hline \multirow{2}{*}{ Profile } & \multirow{2}{*}{ Depth } & \multirow[t]{2}{*}{$\mathrm{pH}_{-\mathrm{H} 2 \mathrm{O}}$} & \multirow{2}{*}{$\begin{array}{c}\text { Org. } \\
\mathrm{C}\end{array}$} & \multicolumn{4}{|c|}{ Exchangeable cations } & \multirow[t]{2}{*}{ Total } & \multirow[t]{2}{*}{ soil-CEC } & \multirow{2}{*}{$\begin{array}{c}\text { Base } \\
\text { sat. }\end{array}$} & \multirow{2}{*}{$\begin{array}{c}1 N \mathrm{KCl} \\
\mathrm{Al}^{3+} \\
\end{array}$} \\
\hline & & & & $\mathrm{Ca}^{2+}$ & $\mathrm{Mg}^{2+}$ & $\mathrm{K}^{+}$ & $\mathrm{Na}^{+}$ & & & & \\
\hline & $\mathrm{cm}$ & & $\%$ & \multicolumn{4}{|c|}{ - } & \multicolumn{2}{|c|}{ - } & \multicolumn{2}{|c|}{$\% \mathrm{cmol}(+) \mathrm{kg}^{-1}$} \\
\hline \multicolumn{12}{|c|}{ P1: Mt. Mand asawu, Ruteng (1,500 m asl.) } \\
\hline A & $0-25$ & 5.1 & 9.24 & 1.71 & 0.40 & 0.13 & 0.18 & 2.42 & 40 & 6 & 0.00 \\
\hline Bw1 & $25-44$ & 5.5 & 7.37 & 1.21 & 0.28 & 0.07 & 0.22 & 1.78 & 40 & 4 & 0.00 \\
\hline 2Bw1 & $44-69$ & 5.9 & 5.23 & 2.77 & 0.24 & 0.05 & 0.06 & 3.12 & 32 & 10 & 0.00 \\
\hline 2Bw2 & $69-108$ & 5.7 & 3.70 & 0.91 & 0.20 & 0.05 & 0.07 & 1.23 & 33 & 4 & 0.00 \\
\hline 2Bw3 & $108-143$ & 5.9 & 2.70 & 0.92 & 0.17 & 0.04 & 0.05 & 1.18 & 31 & 4 & \\
\hline 2Bw4 & $143-173$ & 5.7 & 2.28 & 0.60 & 0.20 & 0.02 & 0.03 & 0.85 & 30 & 3 & \\
\hline \multicolumn{12}{|c|}{ P2: Mt. Wawolika, Bajawa (1,300 m asl.) } \\
\hline A1 & $0-15$ & 6.3 & 7.04 & 21.65 & 2.14 & 0.18 & 0.20 & 24.17 & 32 & 75 & 0.01 \\
\hline A2 & $15-29$ & 6.4 & 6.34 & 11.28 & 0.93 & 0.08 & 0.19 & 12.48 & 27 & 46 & 0.00 \\
\hline Bw1 & $29-53$ & 6.2 & 4.99 & 7.90 & 0.80 & 0.07 & 0.18 & 8.95 & 28 & 32 & 0.00 \\
\hline Bw2 & $53-75$ & 6.2 & 4.84 & 8.81 & 0.86 & 0.07 & 0.18 & 9.92 & 30 & 33 & 0.00 \\
\hline Bw3 & $75-94$ & 6.3 & 4.35 & 9.78 & 0.89 & 0.06 & 0.21 & 10.94 & 29 & 38 & \\
\hline $\mathrm{BC}$ & $94-110$ & 6.3 & 2.43 & 6.41 & 0.67 & 0.02 & 0.14 & 7.24 & 21 & 35 & \\
\hline $\mathrm{C}$ & $110-135$ & 6.4 & 0.57 & 4.95 & 0.56 & 0.02 & 0.10 & 5.63 & 17 & 33 & \\
\hline \multicolumn{12}{|c|}{ P3: Mt. Ambolumbo, Boawae (1,100 m asl.) } \\
\hline A1 & $0-14$ & 6.1 & 6.55 & 14.05 & 2.89 & 0.32 & 0.06 & 17.32 & 23 & 75 & 0.01 \\
\hline A2 & $14-32$ & 5.6 & 4.52 & 6.17 & 0.85 & 0.16 & 0.09 & 7.27 & 14 & 51 & 0.00 \\
\hline Bw1 & $32-62$ & 6.1 & 3.90 & 6.05 & 0.51 & 0.08 & 0.06 & 16.70 & 24 & 28 & 0.00 \\
\hline Bw3 & $62-100$ & 6.3 & 1.97 & 9.66 & 0.32 & 0.04 & 0.06 & 20.08 & 18 & 56 & 0.00 \\
\hline $\mathrm{BC}$ & $100-130$ & 6.3 & 1.15 & 1.56 & 0.14 & 0.02 & 0.25 & 11.97 & 10 & 19 & \\
\hline \multicolumn{12}{|c|}{ P4: Mt. Kelimutu, Ende ( $1,400 \mathrm{~m}$ asl.). } \\
\hline $\mathrm{Ah}$ & $0-16$ & 5.3 & 4.06 & 7.01 & 0.82 & 10.6 & 0.05 & 18.48 & 12 & 66 & 0.23 \\
\hline Bw1 & $16-57$ & 5.6 & 1.80 & 3.73 & 0.43 & 0.08 & 0.09 & 4.33 & 5 & 81 & 0.00 \\
\hline Bw2 & $57-90$ & 5.4 & 0.95 & 1.39 & 0.14 & 0.02 & 0.09 & 1.64 & 4 & 44 & 0.08 \\
\hline $2 \mathrm{Ah}$ & $90-126$ & 5.3 & 2.18 & 2.11 & 0.26 & 0.02 & 0.22 & 2.61 & 7 & 39 & 0.04 \\
\hline $2 \mathrm{Bw}$ & $126-190$ & 5.4 & 0.81 & 0.88 & 0.10 & 0.02 & 0.23 & 1.23 & 4 & 34 & 0.04 \\
\hline \multicolumn{12}{|c|}{ P5: Mt. Egon, Maumere (750 m asl.) } \\
\hline A & $0-15$ & 6.6 & 2.67 & 6.97 & 1.72 & 0.49 & 0.06 & 9.24 & 12 & 78 & 0.00 \\
\hline Bw1 & $15-43$ & 6.6 & 0.98 & 2.94 & 0.91 & 0.45 & 0.05 & 4.35 & 9 & 50 & 0.06 \\
\hline Bw2 & $43-70$ & 6.6 & 0.46 & 2.50 & 0.68 & 0.29 & 0.06 & 3.53 & 7 & 48 & 0.01 \\
\hline 2Bw1 & $70-96$ & 6.4 & 0.46 & 3.66 & 1.02 & 0.40 & 0.11 & 5.19 & 12 & 44 & 0.00 \\
\hline 2Bw2 & $96-150$ & 6.3 & 0.31 & 3.26 & 1.02 & 0.25 & 0.12 & 4.65 & 11 & 43 & 0.00 \\
\hline
\end{tabular}

value of $\left[\left(\mathrm{Al}_{\mathrm{o}}+0.5 \mathrm{Fe}_{\mathrm{o}}\right) \times 15.625\right]+[\%$ volcanic glass $]$ $\geq 36.25$.

All the profiles have $\mathrm{P}$ retention $>85 \%$, that meet the requirements of the second group, except for profile P5. The high $\mathrm{P}$ retention is close related to capability of soils to fix phosphate in adsorption complex; therefore the $\mathrm{P}$ nutrient may not be available to plant.

The content of $\mathrm{Al}_{\mathrm{o}}$ is very high for profile $\mathrm{P} 1$ and $\mathrm{P} 2$, with variation from 25.99 to $53.84 \%$, and from 0.76 to $4.85 \%$ for profile $\mathrm{P} 3, \mathrm{P} 4$ and $\mathrm{P} 5$. While the content of $\mathrm{Fe}_{\mathrm{o}}$ is lower than the $\mathrm{Al}_{\mathrm{o}}$ with variation from 4.68 to $9.43 \%$ for profile $\mathrm{P} 1, \mathrm{P} 2$ and $\mathrm{P} 3$, and from 0.43 to $0.87 \%$ for profile $\mathrm{P} 4$ and $\mathrm{P} 5$. The content of $\left(\mathrm{Al}_{\mathrm{o}}+0.5 \mathrm{Fe}_{\mathrm{o}}\right)$ varied from 7.4 to $57.8 \%$ for profile 88
$\mathrm{P} 1, \mathrm{P} 2$ and $\mathrm{P} 3$, and from 1.2 to $3.1 \%$ for profile $\mathrm{P} 4$ and P5, that fulfill one of the requirements for andic soils both in first and second groups. The high content of $\mathrm{Al}_{\mathrm{o}}$ and $\mathrm{Fe}_{\mathrm{o}}$ reflected the high content of amorphous materials (Table 5).

It should be noted although the $\mathrm{pH}_{\mathrm{NaF}}$ is not to be one of the requirements for andic soil properties; it can be used as indicator for soils that contain of amorphous materials. Data on Table 3 shows that $\mathrm{pH}_{\mathrm{NaF}}$ of all the profiles are high $\left(\mathrm{pH}_{\mathrm{NaF}}\right.$ 11.2-11.9) indicating that the soils contain high amorphous materials. There were clearly observed that the volcanic ash materials had more silica content than the soils derived from volcanic tuff. 
Table 5. Andic soil properties of the profile studied.

\begin{tabular}{|c|c|c|c|c|c|c|c|c|c|c|}
\hline \multirow{2}{*}{ Profile } & \multirow{2}{*}{ Depth } & \multirow{2}{*}{$\begin{array}{c}\mathrm{pH} \\
\mathrm{NaF}\end{array}$} & \multirow{2}{*}{$\begin{array}{c}\mathrm{P} \\
\text { Ret. }\end{array}$} & \multicolumn{4}{|c|}{ Ammonium oxalate extr. } & \multicolumn{2}{|c|}{ Pyrophosphate } & \multirow{2}{*}{$\begin{array}{c}\text { Volcanic } \\
\text { glass }\end{array}$} \\
\hline & & & & $\mathrm{Fe}$ & $\mathrm{Al}$ & $\mathrm{Si}$ & $(\mathrm{Al}+0.5 \mathrm{Fe})$ & $\mathrm{Fe}$ & $\mathrm{Al}$ & \\
\hline \multicolumn{11}{|c|}{$\begin{array}{c}\mathrm{cm} \\
\text { P1: Mt. Mandasawu, Ruteng }(1,500 \mathrm{~m} \text { asl. })\end{array}$} \\
\hline A & $0-25$ & 11.8 & 99 & 8.11 & 40.15 & 26.54 & 44.21 & 1.07 & 5.93 & 22 \\
\hline Bw1 & $25-44$ & 11.9 & 100 & 8.01 & 53.84 & 35.67 & 57.85 & 1.83 & 6.25 & 7 \\
\hline 2Bw1 & $44-69$ & 11.8 & 100 & 8.28 & 52.75 & 34.95 & 56.89 & 2.17 & 5.65 & 2 \\
\hline \multicolumn{9}{|c|}{ P2: Mt. Wawolika, Bajawa (1,300 m asl.) } & & \\
\hline A2 & $15-29$ & 11.5 & 89 & 4.68 & 29.25 & 19.26 & 31.59 & 1.18 & 5.06 & 15 \\
\hline Bw1 & $29-53$ & 11.5 & 62 & 5.91 & 46.99 & 31.10 & 49.95 & 0.60 & 3.76 & 7 \\
\hline $\mathrm{Bw} 2$ & $53-75$ & 11.5 & 64 & 5.91 & 46.37 & 30.69 & 49.33 & 0.48 & 2.98 & 10 \\
\hline \multicolumn{11}{|c|}{ P3: Mt. Ambolumbo, Boawae (1,100 m asl.) } \\
\hline A1 & $0-14$ & 11.3 & 86 & 8.86 & 2.93 & 1.70 & 7.36 & 1.15 & 3.13 & 9 \\
\hline $\mathrm{A} 2$ & $14-32$ & 11.5 & 91 & 9.43 & 3.36 & 1.99 & 8.08 & 1.26 & 3.57 & 13 \\
\hline Bw1 & $32-62$ & 11.6 & 100 & 9.32 & 4.85 & 2.98 & 9.51 & 0.79 & 3.27 & 9 \\
\hline \multicolumn{11}{|c|}{ P4: Mt. Kelimutu, Ende (1,400 m asl.) } \\
\hline $\mathrm{Ah}$ & $0-16$ & 10.7 & 68 & 0.81 & 0.76 & 0.25 & 1.17 & 0.65 & 0.41 & 25 \\
\hline $\mathrm{Bw}$ & $16-57$ & 11.2 & 80 & 0.87 & 1.12 & 0.49 & 1.56 & 0.40 & 0.31 & 25 \\
\hline $2 \mathrm{Ah}$ & $57-90$ & 11.3 & 78 & 0.43 & 1.63 & 0.83 & 1.85 & 0.05 & 0.23 & 28 \\
\hline \multicolumn{11}{|c|}{ P5: Mt. Egon, Maumere (750 m asl.) } \\
\hline A & $0-15$ & & 31 & 0.66 & 1.47 & 0.72 & 1.80 & 0.13 & 0.40 & 4 \\
\hline Bw1 & $15-43$ & 11.4 & 31 & 0.56 & 2.59 & 1.47 & 2.87 & 0.04 & 0.30 & 5 \\
\hline $\mathrm{Bw} 2$ & $43-70$ & 11.3 & 28 & 0.43 & 2.88 & 1.67 & 3.10 & 0.03 & 0.22 & 3 \\
\hline
\end{tabular}

Based on the above requirements for andic soil properties, it is concluded that all the profiles are fulfill the requirements for andic soil properties of the second group. Thus the soils can be classified as Andisols order with subgroup of Thaptic Hapludands (profile P1 and P2), Typic Hapludands (profile P4), and Dystric Haplustands (profile P3 and P5).

\section{Mineral Composition of the Sand and Clay Fraction}

The composition of light minerals of sand fraction for all the profiles is dominated by high hypersthene and augite (pyroxene), green hornblende, and andesine (intermediary plagioclase), and volcanic glass, and rock fragments, with few weathered mineral fragments (Table 6). The composition of heavy minerals of sand fraction is also similar as light minerals, which is dominated by hypersthene, augite and green hornblende. The content of opaque and quartz as resistant minerals are low for all the profiles. This indicates that the weathering process in initial stage. The present of high hypersthene, augite and andesine indicates that the parent materials are classified as intermediary or andesitic volcanic character of the eruption products. This is in agreement with the original geologic description of Suwarna et al. (1990) and Kusumadinata et al. (1990). The amount of weatherable mineral reserve, including volcanic glasses, is very high $(48-81 \%)$. Therefore the soil nutrient reserve is considered high, and in long terms it is expected to supply the nutrient need from the weathered minerals for crop growth.

The results of semi-quantitative determination of the clay mineral composition of the profiles are presented in Table 7 . The composition of clay mineral fraction showed that all the soil profiles have differences of clay mineral. The conditions indicated that the soil had different parent materials containing weathered minerals indicated in the Table 6 . The soils were generally composed dominantly of disordered kaolinite, and small amount of hydrated halloysite in the soils derived from volcanic ash. The soils derived from volcanic tuff had less disordered kaolinitic clay. There is no difference in the composition of clay minerals between the topsoil and subsoil. The soils characteristics of each location had similar chemical properties and mineralogical compositions were reported by Sukarman and Subardja (1997) for Maumere volcanic soils. 
Table 6. Mineral composition of sand fraction of the profile studied.

\begin{tabular}{|c|c|c|c|c|c|c|c|c|c|c|c|c|c|c|c|c|c|c|c|}
\hline \multirow{2}{*}{$\begin{array}{l}\text { Profile } \\
\text { Depth }\end{array}$} & \multicolumn{13}{|c|}{ Light minerals } & \multicolumn{6}{|c|}{ Heavy minerals } \\
\hline & Op & $\mathrm{Qt}$ & Qg & $\mathrm{Fc}$ & $\mathrm{Ze}$ & $\mathrm{Wm}$ & $\mathrm{Rf}$ & $\mathrm{Vg}$ & $\mathrm{Ad}$ & $\mathrm{Sn}$ & $\mathrm{Hg}$ & $\mathrm{Au}$ & Hy & Op & $\mathrm{Hg}$ & $\mathrm{Hc}$ & $\mathrm{Au}$ & Hy & $\mathrm{Ol}$ \\
\hline $\mathrm{cm}$ & \multicolumn{19}{|c|}{ - } \\
\hline \multicolumn{20}{|c|}{ P1: Mt. Mandasawu, Ruteng (1,500 m asl.) } \\
\hline $0-25$ & 3 & 1 & - & 1 & - & 6 & 16 & 22 & 24 & - & 6 & 3 & 18 & 4 & 21 & - & 24 & 55 & - \\
\hline $25-44$ & 7 & 1 & - & 1 & 1 & 7 & 5 & 7 & 12 & - & 13 & 10 & 36 & 10 & 25 & - & 20 & 55 & - \\
\hline $44-69$ & 1 & 1 & 1 & 1 & 2 & 14 & 2 & 2 & 6 & 1 & 21 & 7 & 41 & 3 & 25 & 1 & 13 & 61 & - \\
\hline $69-108$ & 6 & 1 & 2 & 1 & - & 12 & 1 & 1 & 3 & 3 & 22 & 1 & 47 & 12 & 34 & - & 2 & 64 & - \\
\hline $108-143$ & 25 & 1 & - & 1 & - & 11 & 1 & - & 1 & 1 & 8 & 1 & 50 & 37 & 13 & - & 3 & 84 & - \\
\hline $143-173$ & 6 & 3 & 4 & - & 1 & 33 & 3 & - & - & - & 16 & 1 & 33 & 10 & 37 & 2 & 3 & 58 & - \\
\hline $173-210$ & 10 & 6 & 5 & - & 1 & 29 & 3 & - & - & - & 13 & 1 & 32 & 24 & 23 & - & 1 & 76 & - \\
\hline \multicolumn{20}{|c|}{ P2: Mt. Wawolika, Bajawa (1,300 m asl.) } \\
\hline $0-15$ & 5 & - & - & 1 & - & 1 & 16 & 11 & 37 & - & 4 & 5 & 20 & 10 & 5 & - & 24 & 71 & - \\
\hline $15-29$ & 3 & - & - & - & - & 3 & 17 & 15 & 37 & - & 1 & 5 & 19 & 8 & 8 & - & 19 & 73 & - \\
\hline $29-53$ & 3 & - & - & 1 & - & 2 & 15 & 7 & 32 & - & 4 & 10 & 26 & 4 & 20 & - & 27 & 53 & - \\
\hline $53-75$ & 2 & - & - & 1 & - & 1 & 19 & 10 & 32 & - & - & 8 & 27 & 6 & 1 & - & 31 & 68 & - \\
\hline $75-94$ & 1 & - & - & 1 & - & 1 & 18 & 6 & 34 & - & 1 & 9 & 29 & 5 & 2 & - & 26 & 72 & - \\
\hline $94-110$ & 5 & - & - & 1 & - & 2 & 29 & 3 & 28 & - & - & 8 & 24 & 5 & 2 & - & 30 & 67 & 1 \\
\hline $110-135$ & 4 & - & - & 1 & - & 2 & 26 & 4 & 25 & - & - & 8 & 30 & 7 & 3 & - & 35 & 61 & 1 \\
\hline \multicolumn{20}{|c|}{ P3: Mt. Ambolumbo, Boawae (1,100 m asl.) } \\
\hline $0-14$ & 6 & - & 1 & - & - & 3 & 28 & 9 & 21 & - & 2 & 10 & 20 & nd & & & & & \\
\hline $14-32$ & 3 & - & - & - & - & 5 & 29 & 13 & 27 & - & - & 7 & 16 & & & & & & \\
\hline $32-62$ & 4 & - & - & - & - & 5 & 18 & 9 & 27 & - & 1 & 7 & 29 & & & & & & \\
\hline $62-100$ & 6 & - & 1 & - & - & 3 & 19 & 12 & 27 & - & 5 & 9 & 18 & & & & & & \\
\hline $100-130$ & 4 & - & 1 & - & - & 6 & 21 & 6 & 33 & - & 5 & 7 & 17 & & & & & & \\
\hline \multicolumn{20}{|c|}{ P4: Mt. Kelimutu, Ende (1,400 m asl.) } \\
\hline $0-16$ & 3 & - & - & - & 1 & 5 & 31 & 25 & 17 & - & - & 6 & 12 & nd & & & & & \\
\hline $16-57$ & 1 & - & - & - & - & 2 & 35 & 25 & 21 & - & - & 6 & 10 & & & & & & \\
\hline $57-90$ & $\mathrm{sp}$ & - & - & - & - & 1 & 45 & 28 & 15 & - & - & 5 & 6 & & & & & & \\
\hline $90-126$ & 1 & - & - & - & - & 2 & 40 & 23 & 20 & - & - & 6 & 8 & & & & & & \\
\hline $126-190$ & 1 & - & - & - & - & 1 & 32 & 26 & 20 & - & - & 6 & 14 & & & & & & \\
\hline \multicolumn{20}{|c|}{ P5: Mt. Egon, Maumere (750 m asl.) } \\
\hline $15-43$ & 7 & 1 & - & 1 & - & 7 & 15 & 5 & 28 & - & 10 & 9 & 17 & 13 & 33 & - & 26 & 41 & - \\
\hline $43-70$ & 11 & 1 & - & & - & 5 & 14 & 3 & 35 & - & 17 & 4 & 10 & 32 & 54 & - & 16 & 30 & - \\
\hline $70-96$ & 9 & 1 & - & 1 & - & 4 & 8 & 2 & 24 & - & 5 & 14 & 32 & 16 & 11 & - & 35 & 54 & - \\
\hline $96-150$ & 10 & - & - & - & - & 5 & 9 & 2 & 27 & - & 4 & 14 & 29 & 12 & 7 & - & 33 & 59 & 1 \\
\hline
\end{tabular}

Note: $\mathrm{Op}=$ opaque; $\mathrm{Qt}=$ turbid quartz; $\mathrm{Qg}=$ transp. quartz; $\mathrm{Ze}=$ zeolite; $\mathrm{Hi}=$ hydragilite; $\mathrm{Wm}=$ weathered minerals; $\mathrm{Rf}$ = rock fragment; $\mathrm{Vg}=$ volcanic glass; $\mathrm{An}=$ andesine; $\mathrm{Sn}=$ sanidine; $\mathrm{Hg}=$ green hornblende; $\mathrm{Hc}=$ brown hornblende; $\mathrm{Au}=$ augite; $\mathrm{Hy}=$ hyperstine; $\mathrm{nd}=$ not determined.

\section{Land Management Implication for Agricultural Use}

The volcanic soils that were developed in the Flores Island, indicated the conditions influence the characteristics of the soils. At the first places, the parent material of the soils from the volcanic ash, have more fertile with higher cation exchange 90 capacity, and bases. The clay mineralogical of soils derived from volcanic ash tended having more kaolinitic clays than the soils derived from volcanic tuff (Mt. Ambolumbo, Mt. Kelimutu, and Mt. Egon).

The volcanic soils of the island are considered to have good characteristics. It is reflected by thick solum, medium soil texture with friable consistency, 
Table 7. Mineral composition of clay fraction of the profile studied.

\begin{tabular}{|c|c|c|c|}
\hline Depth $(\mathrm{cm})$ & Soil Sub groups & $\begin{array}{c}\text { Disordered } \\
\text { kaolinite }\end{array}$ & $\begin{array}{l}\text { Hydrated } \\
\text { halloysite }\end{array}$ \\
\hline \multicolumn{4}{|c|}{ P1: Mt. Mandasawu, Ruteng (1,500 m asl.) } \\
\hline $0-25$ & Thaptic Hapludands & $H++$ & - \\
\hline $44-69$ & & +++ & \\
\hline $108-143$ & & +++ & \\
\hline \multicolumn{4}{|c|}{ P2: Mt. Wawolika, Bajawa (1,300 m asl.) } \\
\hline $0-15$ & Thaptic Hapludands & & \\
\hline $29-53$ & & +++ & - \\
\hline $75-94$ & & +++ & \\
\hline \multicolumn{4}{|c|}{ P3: Mt. Ambolumbo, Boawae (1,100 m asl.) } \\
\hline $0-14$ & Dystric Haplustands & ++ & + \\
\hline $32-62$ & & ++ & + \\
\hline \multicolumn{4}{|c|}{ P4: Mt. Kelimutu, Ende (1,400 m asl.) } \\
\hline $0-16$ & Typic Hapludands & - & - \\
\hline \multicolumn{4}{|l|}{$57-90$} \\
\hline \multicolumn{4}{|c|}{ P5: Mt. Egon, Maumere (750 m asl.) } \\
\hline $0-15$ & Dystric Haplustands & +++ & + \\
\hline $43-70$ & & +++ & + \\
\hline $96-150$ & & +++ & + \\
\hline
\end{tabular}

Note: $++++=$ predominant $+++=$ dominant $++=$ moderate $;+=$ minor $;-=$ not detected.

fertile, and easy to tillage and root crop growth. The organic materials are high especially in top soils, soil $\mathrm{pH}$ is slightly acid to acid, and moderate to low content bases, which are to be favorable condition for nutrient availability to crop growth. Beside that, the amount of weather-able mineral reserve is considered very high which could support to nutrient supply for long terms. The climatic conditions were clearly shown in their amount of weathered minerals. The western part of the island has more rain.

The main problem of the volcanic soils for agricultural use is slope steepness. It has potential to erosion and landslide, especially for the soils planted with annual crops if it is often to tillage periodically, and the surface soils becomes open without vegetation. To solve the problem, it is recommended to apply soil conservation technique properly, such as terracing, raised bed terrace, and contour planting. Suganda et al. (1999) mentioned that contour planting was the best method for controlling runoff and soil loss in highland vegetable cultivation. The other problem is the high $\mathrm{P}$ retention, which can reduce the availability of soil $\mathrm{P}$ to crops, so that it is need a higher dosage of $\mathbf{P}$ fertilizer. Increasing organic materials is very suggested to maintenance high status of soil organic materials such as using crop residue after harvesting.

\section{CONCLUSIONS}

The soils developed from volcanic ash parent materials in Flores Island showed different properties compared to the soils derived from volcanic tuff, even though they were developed from the same intermediary volcanic materials. The silica contents, clay mineralogy and sand fractions, were shown as the differences. The different in climatic conditions developed similar properties such as deep solum, dark color, medium texture, and very friable soil consistency. The soils have high organic materials, slightly acid to acid, low to medium CEC. The soils in western region have higher clay content and showing more developed than of the eastern region. All the profiles meet the requirements for andic soil properties, and classified as Andisols order.

The mineral composition of sand fraction was dominated by andesine-hornblende-augitehypersthene association, except soil profile from Mt. Kelimutu was dominated by volcanic glassesandesine-augite-hypersthene association. The mineral composition of clay fraction was dominated by disordered kaolinite and disordered halloysite. The high mineral reserve could supply the nutrient need for crop growth for long terms.

The volcanic soils have good soil characteristics which can support increasing agricultural production 
both annual and perennial crops. The land management for the land should be focused on the increasing organic materials and P nutrient, and soil conservation to control soil erosion and land slide.

\section{REFERENCES}

Alkasuma and RB Badayos. 2003. The mineralogical characteristics of volcanic soils from North Lampung, Sumatra Indonesia. Indon J Soil Clim 21: 56-68.

Arifin M dan S Hardjowigeno. 1997. Pedogenesis of Andisols from andesitic and basaltic volcanic materials in some agroclimatic zones in the tee estate, West Java, Indonesia. In: Subagjo et al. (eds). Proc. of $6^{\text {th }}$ National Conggress of Indonesian Soil Science Association. Book II. Bogor, pp. 17-32.

Blakemore LC, PL Searle, and BK Daly. 1987. Methods for chemical analysis of soils. N.Z. Soil Bereau Scientific Report 80. N.Z. Soil Bereau, Lower Hutt, New Zealand, $103 \mathrm{p}$.

Burt R. 2004. Soil Survey Laboratory Methods Manual . Soil Survey Investigation Report No. 42. Version 4. USDA- NRCS National Survey Center. 700 p.

Buurman P. 1990. Chemical, Physical, and mineralogical characteristics for the soil data base. Tech. Report No.7, Ver. 2.1. LREPP Part 2. Soil Data Base Management. CSAR, Bogor.

Buytaerta W, J Deckers and G Wyseure. 2007. Regional variability of volcanic ash soils in South Ecuador: the relation with parent materials, climate, and land use. Catena 70 (2): 143-154.

Dudal R and M Soepraptohardjo. 1960. Some considerations on the genetic relationship between Latosols and Andosols in Java (Indonesia). Trans. of the $7^{\text {th }}$ Int. Congr. of Soil Sci. IV. Madison, Wisconsin, USA. Vol. 4: 229-237.

Fauzi AI and G Stoops. 2004. Reconstruction of a topsequence on volcanic material in the Honje Mountains, Ujung Kulon Peninsula, West Java. Catena 56: 45-66.

Fiantis D and E. Van Rast. 1997. Properties of volcanic ash soil from the Merapi and Talamau volcanoes in West Sumatra, Indonesia. In: Subagjo et al. (eds). Pros. Kongres Nasional VI HITI. Buku II. Himpunan Ilmu Tanah Indonesia, pp. 1-15.

Hikmatullah. 2008. Andisol from Tondano area, North Sulawesi: properties and classification. J Trop Soils 13: 77-85.

Koesoemadinata S, Y Noya and Kadarisman. 1981. The Geology of Ruteng Quadrangle, East Nusa Tenggara, scale 1:250.000. Geological Research and Development Centre, Bandung, Indonesia.

Leamy ML. 1984. Andisols of the world. Congr. Int. Volcanic Soils Comm. 13. Univ. Laguna Secr. Publ, pp. 368-387.
Madeira M, A Furtado, E Jeanroy and AJ Herbillon. 1994. Andisols of Madeira island (Portugal); characteristics and classification. Geoderma 62: 363-383.

Moustakas NK and F Georgoulias. 2005. Soils developed on volcanic materials in the island of Thera, Greece. Geoderma 129: 125-138.

Nanzyo M. 2002. Unique properties of volcanic ash soils. Global Environ Res 6 (2): 99-112.

Nanzyo M, S Shoji and R Dahlgren. 1993. Physical characteristics of volcanic ash soils. In: S Shoji, M Nanzyo and R Dahlgren (eds) Volcanic ash soilsgenesis, properties, and utilization. Development in Soil Science 21. Elsevier, Amsterdam, pp. 189-207.

Niuwenhuyse A, AG Jongmans, N Van Breemen. 1993. Andisol formation in a Holocene beach ridge plain under the humid tropical climate of the Atlantic coast of Costa Rica. Geoderma 57: 423-442.

Nizeyimana E. 1997. A toposequence of soils derived from volcanic materials in Rwanda: morphological, chemical, and physical properties. Soil Sci 162: 350360.

Parfitt RL, M Russel and GE Orbell. 1983. Weathering sequence of soils from volcanic ash involving allophane and halloysite New Zealand. Geoderma 29: 41-57.

Prado B, C Duwig, C Hidalgo, D Gomez, H Yee, C Prat, M Esteves and JD Etchevers. 2007. Characterization, functioning and clasification of two volcanic soil profiles under different land uses in Central Mexico. Geoderma 139: 300-313.

Schmidt FH dan JHA Ferguson. 1951. Rainfall types based on wet and dry period ratios for Indonesia and Western New Guinea. Verh 42. Jaw Meteo dan Geofisik. Jakarta.

Shoji S and T Ono. 1978. Physical and chemical properties and clay mineralogy of Andosols from Kitakami, Japan. Soil Sci 126: 297-312.

Shoji S, T Takahashi, T Ito and CL Ping. 1988. Properties and classification of selected volcanic ash soils from Kenai Peninsula, Alaska. Soil Sci 145: 395-413.

Shoji S, M Nanzyo and RA Dahlgren. 1993. Volcanic ash soils. Genesis, properties and utilization. Dev in Soil Science 21. Elsevier, 288 pp.

Soil Survey Staff. 2006. Keys to soil taxonomy. $10^{\text {th }} \mathrm{ed}$. Natural Resources Conservation Service. USDA, Washington DC.

Subagyo H, AB Siswanto and N Suharta. 2000. Agricultural lands in Indonesia. In: Adimihardja et al. (eds). Indonesian Land Resources and Their Management. Center for Soil and Agroclimate Research. Agricultural Research and Development, Bogor, pp. 21-65 (in Indonesian).

Suganda H, H Kusnadi and U Kurnia. 1999. The effect of row planting direction and raised bed on ersion control in highland vegetable cultivation. Indon Soil Climate J 17: 55-64 (in Indonesian). 
Sukarman H, HDjohar and A Sofyan. 1993. Assessment of tickness class of Mt. Tambora ash cover to differentiate soil mapping unit in Soriutu plain, Dompu Regency, West Nusa Tenggara. In: H. Suhardja et al. (Eds) Proceeding Technical Meeting of Soil and Agroclimate Research, Bogor, pp. 175184.

Suwarna N, S Santosa and S Kusumadinata. 1990. The Geology of Ende Quadrangle, East Nusa Tenggara scale 1:250.000. Geological Research and Development Centre, Bandung, Indonesia.

Tan KH. 1965. The Andosols in Indonesia. Soil Sci 99: 375-378.

Tan KH. 1998. Andosol. Program Studi Ilmu Tanah. Program Pascasarjana Universitas Sumatera Utara Medan. 75 p.

Takahashi T and S Shoji. 2002. Distribution and classification of volcanic ash soils. Global Environ Res 6: 83-97.

Van Schuylenborgh J. 1957. On the genesis and classification of soils derived from andesitic tuffs under humid tropical conditions. Neth J Agric Sci 5: 99-123.
Van Bemmelen RW. 1970. The geology of Indonesia Vol. IA. General geology of Indonesia and adjacent archipelagoes. $2^{\text {nd }}$ ed. Martinus Nijhoff, The Hague, The Netherlands.

Van Ranst E, SR Utami and J Shamshuddin. 2002. Andisols on volcanic ash from Java Island, Indonesia: Physicochemical properties and classification. Soil Sci 167: 68-79.

Van Wambeke A, P Hastings and P Tolomeo. 1986. New Simulation Model (NSM) for Moisture Regimes. Dep Agr Bradfield Hall. Cornell University. NY.

Wada K. 1985. The distinctive properties of Andosols. In: Steward B.A. (Ed). Advance in Soil Sci Vol 2, Springer New York, pp 173-229.

Wada K, Y Kakuto and H Ikawa. 1986. Clay minerals, humus complexes, and classification of four Andepts of Maui Hawaii. Soil Sci Soc Am J 50: 1007-1013.

Yatno E dan S Zauyah. 2008. Properties and management implications of soils formed from volcanic materials in Lembang area, West Java. Indon J Agric Sci 9 (2): 44-54.

Zehetner F, WP Miller and LT West. 2003. Pedogenesis of volcanic ash soils in Andean Ecuador. Soil Sci Soc Am J 67: 1797-1803. 